Journal of Qualitative Criminal Justice \& Criminology

\title{
Book Review | Once Upon a Place: The Fading of Community in Rural Kentucky
}

Travis Linnemann ${ }^{1}$

${ }^{1}$ Old Dominion University

Published on: Apr 01, 2014

DOI: $10.21428 / 88 d e 04 a 1 . b 584608 a$

License: Creative Commons Attribution 4.0 International License (CC-BY 4.0). 
Kenneth D. Tunnell. Once Upon a Place: The Fading of Community in Rural Kentucky. Xlibris, 2011; 123 pp.; ISBN: 9781462875658.

It is difficult to think of the rural apart from rolling hills and green fields that offer a respite from the city's disquiet. Along with images of a bucolic rurality however, is a darker anti-idyll that has loomed in the social imaginary for centuries. While the narrative is timeless, the rural's decline is something few among us have lived or even cared to witness first-hand. However, in the pages of Kenneth D. Tunnell's Once Upon a Place, we travel to the disregarded landscapes of rural Kentucky and witness the history of its struggles. Like looking out the window of an old pickup truck as it bounces down a country road, Tunnell delivers us to the various sites where the time honored rural idyll is vanishing. This is a story of a land where tobacco once was, but no longer is king. With serious but accessible academic writing animated by more than 60 mournful photos, Once Upon a Place documents the abandoned farms, decaying buildings and lives cut adrift in a shifting and uncertain political economy.

Beginning with a brief history of Kentucky's farm economy, Tunnell runs down a list of important points in space and time that lead us to the present. Here, the demise of "Big Tobacco" had immediate and devastating effects on rural families, their modest homes and towns. With both prose and picture, Tunnell then details how the Federal Government's attempts to address widening inequality have largely failed, leaving many of the remaining residents clinging to agricultural day labor and manufacturing jobs under less than ideal conditions. Once Upon a Place next turns to the ruin of big box retailers as they extract labor and capital from rural Appalachia like the coal dug from its hills. With heart wrenching depth and clarity, Tunnell shows how neoliberal capitalism has gutted local economies and trampled the land with Wal-Mart parking lots - not unlike the mountains flattened and hollowed out by abandoned mines. Pairing a photographer's trained eye with sharp sociological insight, Tunnell then describes how these abandoned socially disorganized rural communities are locked in a spiral of out-migration, aging populations and grim poverty. It is this spiral of structural inequalities, he contends, that makes a particular sort of protestant, populist patriotism an organizing feature of everyday community life.

From vanishing family farms, abandoned company stores, roadside trash dumps, to small rural churches, to read Once Upon a Place, is to experience the lived and unfolding history of rural Kentucky. Because of Tunnell's keen eye and accessible writing, the book will certainly interest those concerned with rural poverty and inequality. However, it is also sure to interest specialized academic audiences in rural sociology, anthropology and criminology - just to name a few. Summoning the spirit of James Agee and Walker Evans' Let Us Now Praise Famous Men, the book also provides a useful roadmap for those interested in taking up this sort of critical visual ethnography. So put on Levon Helm or John 
Prine in background, dive into the pages of Once Upon a Place and visit the fading communities of rural Kentucky-while you still can. 